\title{
BMJ Global Health Covid-19 and mobile phone hygiene in healthcare settings
}

\author{
Sunil Kumar Panigrahi, Vineet Kumar Pathak (D) , M Mohan Kumar, Utsav Raj, \\ Karpaga Priya $\mathrm{P}$
}

To cite: Panigrahi SK, Pathak VK, Kumar MM, et al. Covid-19 and mobile phone hygiene in healthcare settings. BMJ Global Health 2020;5:e002505. doi:10.1136/ bmjgh-2020-002505

Handling editor Seye Abimbola

Received 17 March 2020

Revised 3 April 2020

Accepted 4 April 2020

\section{Check for updates}

(C) Author(s) (or their employer(s)) 2020. Re-use permitted under CC BY-NC. No commercial re-use. See rights and permissions. Published by BMJ.

Community and Family Medicine, AllMS Raipur, Raipur, Chhattisgarh, India

Correspondence to Dr Vineet Kumar Pathak; pathakvineet2089@gmail.com

\section{MOBILE PHONES IN HEALTHCARE SETTINGS}

Hospitals and other healthcare settings can facilitate the spread of infectious diseases. ${ }^{1}$ The recent outbreak of covid-19 is the third documented spillover of animal coronavirus to humans in the past two decades, after severe acute respiratory syndrome (SARS) in 2002 and the Middle East respiratory syndrome in 2012. It has brought the focus of disease epidemiology to the healthcare institutions. The index case which sets the motion of outbreak investigations and subsequent control measures are initiated only after coming in contact with the healthcare institutions. ${ }^{2}$

Hospitals without proper infection control measures are a liability during an epidemic. ${ }^{3}$ They may become sources of hospital-acquired infections. They may initiate a vicious cycle of new disease diagnosis and newly acquired infections, both simultaneously occurring in the same hospital. For any infectious disease, it is the mode of transmission that bridges the source or reservoir with a susceptible host. It is this point which needs to be interrupted to prevent and control further disease transmission. ${ }^{4}$ Healthcare professionals are a bridge between infectious patients in hospitals (core population) and the general population in transmitting the disease.

The things they use within the hospital premises may facilitate such disease transmission. ${ }^{1}$ These include mobile phones. Globally, there are 5.07 billion $^{5}$ mobile phone users. There are almost 1.2 billion $^{6}$ users in India alone; $23 \%$ of mobile phone users globally are in India. Based on mobile phone usage, India is placed second only next to China. ${ }^{7}$ It is important for healthcare professionals to use mobile phones in the hospital and other health and care settings, especially for communication.

\section{COVID-19, MOBILE PHONES AND DISEASE EPIDEMIOLOGY}

There have been recent discussions on curbing the use of white coats as a way of
Summary box

Covid-19 is now a global pandemic. There is some evidence to suggest possible fomite transmission. Hence, inanimate objects play a significant role in their transmission.

- In this commentary, we discuss 'mobile phones' as a potential vector of severe acute respiratory syndrome-CoV-2 spread. The use of mobile phones has not been restricted in hospital and other healthcare settings. Hence, mobile phones could be a missing link in controlling the covid-19 pandemic.

- We recommend, as part of efforts to control the covid-19 pandemic, awareness of 'mobile phone hygiene'; restriction of mobile phone use in healthcare settings; avoiding the sharing of mobile phones, headphones or headsets of any kind; and widely disseminated advice from mobile companies, governments and WHO on how to disinfect mobile phones.

preventing hospital-acquired infection. ${ }^{8}{ }^{9}$ However, mobile phones are arguably much more commonly and extensively used by healthcare professionals compared with white coats. Apart from social media use, health professionals use mobile phones to follow health-related news; communicate with one another; look up updated guidelines, drug interactions, adverse events and health research; for photography, sharing medical documents, conducting teleconsultations and patient tracking; all resulting in extensive use of mobile phones. ${ }^{10}$ The self-reported use of mobile phones among health workers ranges from once in every $15 \mathrm{~min}$ to once in 2 hours. $^{11}$

Mobile phones are one of the most highly touched surfaces according to the Centers for Disease Control and Prevention (CDC), along with counters, tabletops, doorknobs, bathroom fixtures, toilets, keyboards, tablets and bedside tables. ${ }^{12}$ During the ongoing covid-19 pandemic, hand hygiene has been recommended as a mainstay of infection control by all prominent health societies, including 
WHO. ${ }^{13}$ Hand washing not only reduces the individual risk of transmission but also interrupts the community transmission of SARS-CoV-2, the virus that causes covid19. However, mobile phone surfaces are a peculiar 'highrisk' surface, which can directly come in contact with the face or mouth, while talking over phone, even if hands are properly washed and clean.

In their tendency to come in direct contact with the face, nose or eyes in healthcare settings, mobile phones are perhaps second only to masks, caps or goggles. However, they are neither disposable nor washable like these other three, thus warranting disinfection. Mobile phones can effectively negate hand hygiene, as there can often be seemingly compulsive and frequent use of mobile phones immediately after hand washing or hand rubbing with alcohol-based sanitizers. There is growing evidence that mobile phones are a potential vector for pathogenic organisms. ${ }^{1415}$

A recently published literature review showed that mobile phone contamination rates range from $40 \%$ to $60 \%$. Coagulase-negative Staphylococcus and S. aureus were the most frequent bacteria $(10 \%-90 \%)$, and most of them were methicillin resistant. ${ }^{16}$ There is evidence of mobile phones getting contaminated by viruses in hospital settings. In a study, $10 \%$ of phones which were tested had viral pathogens. ${ }^{17}$ Studies have also reported medical students to have four times higher odds of having heavy growth of microbes on their mobile phones. ${ }^{11}$ These findings are particularly important, given the evidence in a recent review, which included 22 studies, that coronavirus can survive on inanimate surfaces like metal, glass or plastic surface for 2 hours to 9 days, and that high temperature such as $30^{\circ} \mathrm{C}$ or $40^{\circ} \mathrm{C}$ reduced the duration of persistence. ${ }^{18}$

\section{MOBILE PHONE HYGIENE: BETTER SAID THAN DONE}

SARS-CoV-2, the virus that causes covid-19, is only 3 months old, and so our understanding of the disease epidemiology is continuously evolving. However, there are many significant guidelines from various health organisations (eg, WHO and CDC) focusing on prevention and control of disease spread. However, there is no mention of or focus on mobile phones in these guidelines, including the WHO infection control and prevention guideline, which recommends the use of hand washing as being of the highest importance of universal precautions. It is the need of the hour to address a proper hygienic use of mobile phones in healthcare settings. ${ }^{12} 13$ In a study in India, almost $100 \%$ of health workers of a tertiary care hospital used mobile phones in the hospital, but only $10 \%$ of them had at any time wiped their mobile phones clean. ${ }^{19}$

There seems to have been some initial agreement that more than $50 \%$ of alcohol damages mobile screen, whereas many microorganisms, including SARS-CoV-2, do not respond to concentrations below $55 \%$ of alcohol. ${ }^{20}$ Two of the biggest mobile phone companies (Apple and
Samsung) do not recommend any chemical or spray to clean the mobile phone screen prior to covid-19. ${ }^{21} 22$ However, amidst the ongoing pandemic of covid-19, both Apple and Samsung have revised their user support guidelines, saying that $70 \%$ isopropyl alcohol or Clorox Disinfecting Wipes can be used to gently wipe the exterior surface of phones in switched-off mode. However, in doing so, the use of bleach or entry of moisture through any of the openings must be avoided, and any harsh chemical may damage the oleophobic screen, leading to damage in the touch screen sensitivity of the phone. ${ }^{21} 22$

\section{MOBILE PHONE HYGIENE: THE WAY FORWARD}

We recommend mobile phone use restrictions in healthcare institutions especially in hospital wards, operating theatres and intensive care units. Disposable/washable transparent polythene mobile phone covers may be mandated for mobile phones that are brought into and used in hospital premises. Use of headphones or headsets (wired/wireless) should be promoted to prevent contact with the face while talking on mobile phones. There should be no sharing of mobile phones, headphones or headsets of any kind. In addition, where available, the use of interdepartmental intercom facility though telephones may be promoted as a strategy for reducing excessive use of personal mobile phones inside hospital premises.

Further, organisations such as the WHO and CDC should mobilise mobile manufacturing companies to issue advisory on the choice of disinfectants in view of product damage. Compulsory hand washing with soap and water or alcohol-based hand rubs should be practised after unavoidable mobile phone use. Organisational research should be promoted through identification of bacterial or viral flora on mobile phones, and appropriate use of disinfectants according to the culture and sensitivity pattern should be included in hospital infection control measures.

There has never been any concrete evidence that mobile phone hygiene has reduced disease transmission. Having said that, minimising mobile phone use, hand washing, disinfectant wipes, headphone use and washable covers should be encouraged. Complete mobile phone restriction in the current situation would be near impossible and may contribute to a breakdown of communication in a time when swift and open lines of communication are crucial. The available recommendation from the mobile phone industry is to use biocide (70\% isopropyl alcohol or Clorox Disinfecting Wipes) for cleaning mobile phones routinely, in the following steps:

- Before starting to clean, turn off the phone and remove the case, accessories and cables, if any.

- Use a soft, lint-free, waterproof and dust-proof wipe, such as a camera lens wipe, to gently wipe the surface of the device.

- Lightly dampen a corner of a washcloth with a small amount of biocide and gently wipe the front and back of the phone. 
- Avoid entry of moisture through any openings and do not use liquid directly on the phone.

- Do not use the compressor and do not use or spray bleach or any cleaning solutions directly on phone.

- Do not use bleach.

\section{CONCLUSION}

The CDC recommends hand hygiene before and after contact with every patient, and an estimated one-third of hospital-acquired infections are caused by lack of adherence to established infection control practices such as hand hygiene. ${ }^{13}$ Although hand hygiene and mobile phone use by a person are not mutually exclusive, it is high time to acknowledge the potential role of mobile phones in disease transmission cascade and to take evidence-based appropriate actions. This is especially important, given the ongoing covid-19 pandemic. To this end, it is necessary for government agencies and the WHO to generate public awareness and to formulate suitable information, education and communication material on mobile phone hygiene, especially in healthcare settings.

Contributors All the authors were involved in the concept, design, literature search, manuscript preparation, manuscript editing and manuscript review, and acted as guarantors.

Funding The authors have not declared a specific grant for this research from any funding agency in the public, commercial or not-for-profit sectors.

Competing interests None declared.

Patient consent for publication Not required.

Provenance and peer review Not commissioned; externally peer reviewed.

Data availability statement There are no data in this work.

Open access This is an open access article distributed in accordance with the Creative Commons Attribution Non Commercial (CC BY-NC 4.0) license, which permits others to distribute, remix, adapt, build upon this work non-commercially, and license their derivative works on different terms, provided the original work is properly cited, appropriate credit is given, any changes made indicated, and the use is non-commercial. See: http://creativecommons.org/licenses/by-nc/4.0/.

ORCID iD

Vineet Kumar Pathak http://orcid.org/0000-0003-2788-8399

\section{REFERENCES}

1 Collins AS. Chapter 41. Preventing health care-associated infections. In: Patient safety and quality: an evidence-based Handbook for nurses, 2020. https://www.ncbi.nlm.nih.gov/books/ NBK2683/
2 Centers for Disease Control and Prevention. Principles of epidemiology: lesson 6, section 2, Self-Study course SS1978. Available: https://www.cdc.gov/csels/dsepd/ss1978/lesson6/ section2.html [Accessed 19 Mar 2020].

3 World Health Organization. Hospital preparedness for epidemic. Available: https://www.who.int/publications-detail/hospitalpreparedness-for-epidemics [Accessed 19 Mar 2020].

4 Detels R, Gulliford M, Karim QA. Oxford textbook of global public health. Oxford, UK: Oxford University Press, 2015. https:// oxfordmedicine.com/view/10.1093/med/9780199661756.001.0001/ med-9780199661756

5 Abdulla MA, Esmaeel AM. Providing information through smart platforms: an applied study on academic libraries in Saudi universities. J Educ Soc Behav Sci 2019:1-24.

6 Government of India. Home, Telecom regulatory authority of India. Available: https://main.trai.gov.in/ [Accessed 19 Mar 2020].

7 Highlights of Telecom subscription data as on 31st January, 2019. Available: https://main.trai.gov.in/sites/default/files/PR_No. 22of2019_0.pdf [Accessed 19 Mar 2020].

8 Banu A, Anand M, Nagi N. White coats as a vehicle for bacterial dissemination. J Clin Diagn Res 2012;6:1381-4.

9 Fernandes E. Doctors and medical students in India should stop wearing white coats. BMJ 2015;351:h3855.

10 Jayalakshmi J, Appalaraju B, Usha S. Cellphones as reservoirs of nosocomial pathogens. J Assoc Physicians India 2008;56:388-9.

11 Chao Foong Y, Green M, Zargari A, et al. Mobile phones as a potential vehicle of infection in a hospital setting. $J$ Occup Environ Hyg 2015;12:D232-5.

12 Centers for Disease Control and Prevention. Preventing 2019$\mathrm{nCoV}$ from spreading to others. Available: https://www.cdc. gov/coronavirus/2019-ncov/hcp/guidance-prevent-spread.html [Accessed 19 Mar 2020].

13 World Health Organization. Infection prevention and control during health care when novel coronavirus (nCoV) infection is suspected. Available: https://www.who.int/publications-detail/infectionprevention-and-control-during-health-care-when-novel-coronavirus-( ncov)-infection-is-suspected-20200125

14 Brady RRW, Wasson A, Stirling I, et al. Is your phone bugged? the incidence of bacteria known to cause nosocomial infection on healthcare workers' mobile phones. J Hosp Infect 2006;62:123-5.

$15 \mathrm{Pal}$ S, Juyal D, Adekhandi S, et al. Mobile phones: reservoirs for the transmission of nosocomial pathogens. Adv Biomed Res $2015 ; 4: 144$

16 Morvai J, Szabó R. [The role of mobile communication devices in the spread of infections]. Orv Hetil 2015;156:802-7.

17 Cavari Y, Kaplan O, Zander A, et al. Healthcare workers mobile phone usage: a potential risk for viral contamination. surveillance pilot study. Infect Dis 2016;48:432-5.

18 Kampf G, Todt D, Pfaender S, et al. Persistence of coronaviruses on inanimate surfaces and their inactivation with biocidal agents. $J$ Hosp Infect 2020;104:246-51.

19 Shakthivel PCG, G. Sucilathangam GV, Revathy C. Mobile phones in healthcare setting: potential threat in infection control. Int J Curr Microbiol Appl Sci 2017;6:706-11.

20 The Wall Street Journal. Should you clean your phone to combat coronavirus? Definitely. Maybe. Available: https://www.wsj.com/ articles/should-you-clean-your-phone-to-combat-coronavirusdefinitely-maybe-11584018237 [Accessed 19 Mar 2020].

21 Apple Support. Cleaning your iPhone. Available: https://support. apple.com/en-in/HT207123 [Accessed 19 Mar 2020].

22 Samsung Support NZ. Galaxy note 8: how to clean dirty glass/ screen? Available: https://www.samsung.com/nz/support/mobiledevices/galaxy-note-8-how-to-clean-dirty-glass-screen/ [Accessed 19 Mar 2020]. 